\title{
Pengaruh virus corona (covid-19) terhadap kinerja ruas jalan disekitar pabrik GSI Sukalarang
}

\author{
Asti Mirdianti a,1, ${ }^{\mathrm{N}}$, Paikun a,2, \\ a Program Studi Teknik Sipil Universitas Nusa Putra, Sukabumi, Indonesia \\ 1 asti.mirdianti_ts16@nusaputra.ac.id*; ${ }^{2}$ paikun@nusaputra.ac.id \\ * Corresponding Author
}

Received 26 September 2020; revised 20 Februari 2021; acceted 31 Maret 2021

\section{ABSTRAK}

Sejak pabrik-pabrik beroperasi telah memberikan dampak berupa kemacetan yang terjadi di ruas Jalan Sukabumi-Cianjur, persisnya depan pabrik P.T. Glostar Indonesia (GSI) pada posisi Km.13 sampai akses masuk jalan baru PT. Pratama Abadi Industri. Namun saat ini dunia di gemparkan dengan virus yang di namai Corona Virus atau Covid-19 yang telah terjadi beberapa bulan terakhir ini di Indonesia pada tahun 2020. Tentunya hal ini akan berdampak pada semua aspek termasuk tingkat pelayanan jalan, makan dibuatlah penelitian perbadingan kinerja ruas jalan disekitar pabrik GSI Sukalarang dari hatun 2017 dengan tahun 2020. Dari hasil survei dan perhitungan, maka dapat disimpulkan bahwa kinerja ruas Jalan dengan tingkat layanan di kawasan pabrik GSI saat ini (tahun 2020) di bandingkan dengan tahun sebelumnya (tahun 2017) di lokasi yang sama mengalami penurunan yang ditandai dengan berkurangnya volume kendaraan, kecepatan kendaraan menurun, kepadatan kendaraan berkurang, dan tingkat pelayanannya baik. Dari data yang diperoleh maka Pandemi Covid-19 berpengaruh terhadap volume lalu lintas dan kinerja ruas jalan, sehingga mengalami penurunan volume kendaraan di tahun 2020. Di tahun 2017 volume lalu lintas pada hari Sabtu yaitu 21684 kendaraan dan 8407,8 smp/jam untuk tahun 2020 hari Sabtu yaitu 10471 kendaraan dan 5500,6 smp/jam mengalami penurunan sebanyak 48,3\%. Sementara di tahun 2017 volume lalu lintas pada hari Senin yaitu 26430 kendaraan dan 9467,35 smp/jam, untuk tahun 2020 hari Senin yaitu 23740 kendaraan dan 9623,85 smp/jam mengalami penurunan sebanyak $10,18 \%$

\section{The influence of the corona virus (covid-19) on the road performance setions around the gsi sukalarang factory}

\section{ABSTRACT}

Since the factories began operating, they had an impact in the form of congestion that occurred on Jalan Sukabumi-Cianjur, precisely in front of the P.T. Glostar Indonesia (GSI) at the position of Km.13 until the new road access to PT. Pratama Abadi Industri. However, currently the world is in an uproar with a virus called Corona Virus or Covid-19 which has occurred in the last few months in Indonesia in 2020. Of course this will have an impact on all aspects including the level of road service, so a comparative study of road performance is made. around the GSI Sukalarang factory from Hatun 2017 to 2020. From the survey and calculation results, it can be concluded that the performance of roads with service levels in the current GSI factory area (2020) compared to the previous year (2017) at the same location has decreased which is indicated by reduced vehicle volume, vehicle speed. decreased, reduced vehicle density, and good service levels. From the data obtained, the Covid-19 Pandemic has an effect on traffic volume and road performance, resulting in a decrease in vehicle volume in 2020. In 2017 the traffic volume on Saturdays was 21684 vehicles and 8407.8 SMP / hour, for 2020 on Saturdays, namely 10471 vehicles and 5500.6 SMP / hour decreased by $48.3 \%$. While in 2017 the traffic volume on Monday was 26430 vehicles and 9467.35 SMP / hour, for 2020 Monday, namely 23740 vehicles and 9623.85 SMP / hour decreased by 89.9\%.

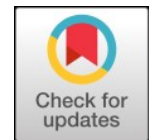

KATA KUNCI

Lalu lintas

Kinerja ruas jalan Pengaruh covid-19 Pandemi covid-19 Sekitar pabril

\section{KEYWORDS}

Traffic

Road performance Effect of covid-19 Covid-19 pandemic Around factory 


\section{Pendahuluan}

Sejak pabrik-pabrik beroperasi telah memberikan dampak berupa kemacetan yang terjadi di ruas Jalan Sukabumi-Cianjur, persisnya depan pabrik P.T. Glostar Indonesia (GSI) pada posisi Km.13 sampai akses masuk jalan baru PT. Pratama Abadi Industri, khusunya pada saat jam karyawan masuk kerja dan waktu jam pulang kerja [1]. Kondisi kemacetan yang panjang mengakibatkan waktu tempuh bertambah, konsumsi bahan bakar yang meningkat, dampak emisi menjadi sangat tinggi di lokasi tersebut [2]. Ruas jalan tersebut sering kali tidak bisa diandalkan oleh masyarakat umum untuk kebutuhan perjalanan seharihari maupun untuk kebutuhan mendesak seperti ambulan, pemadam kebakaran dan lain-lainnya pada saat terjadi kondisi darurat [3]. Untuk menentukan perbaikan kondisi lalu lintas di lokasi ini diperlukan terlebih dahulu analisis kinerja ruas Jalan Sukabumi-Cianjur di tahun 2020. Saat ini dunia di gemparkan dengan virus yang di namai Corona Virus atau Covid-19 yang telah terjadi beberapa bulan terakhir ini di Indonesia pada tahun 2020. Virus Covid-19 ini dianggap alami dan berasal dari hewan, melalui infeksi spillover [4]. Asal sebenarnya tidak diketahui tetapi kasus infeksi pertama yang diketahui terjadi di Wuhan Cina [5]. Untuk memutuskan rantai penularan, pemerintah menghimbau untuk tidak membuat suatu kerumunan dan atau melakukan kontak fisik secara langsung bahkan pemerintah menerapkan PSBB di beberapa daerah kususnya yang di daerah bagian zona merah dan Sukabumi pun menerapkan PSBB tersebut, semua aktifitas diberhentikan dan tidak boleh ada yang keluar rumah kecuali ada kepentingan yang sangat penting [6].

Hal itu tentunya akan berdampak pada perekonomian, pemerintahan, pendidikan, sosial budaya dan lain-lain yang tentunya akan berdampak juga pada kinerja jalan [7]. Maka dari itu penulis akan melakukan perbandingan kinerja jalan dengan tingkat layanan di kawasan GSI pada tahun sebelumnya 2017 dengan tahun sekarang 2020 saat terjadi wabah Covid-19. Penelitian ini dapat berkontribusi terhadap rekayasa lalu lintas untuk meminimalisir kemacetan khususnya pada jalan di ruas Jalan Sukabumi-Cianjur, persisnya depan pabrik P.T. Glostar Indonesia (GSI) pada posisi Km.13 sampai akses masuk jalan baru PT. Pratama Abadi Industri dan umumnya di Kawasan pabrik-pabrik yang mempunyai kemiripan karakteristik.

\section{Metodologi}

\subsection{Program Kerja}

Kegiatan survei dilakukan berdasarkan program kerja yang saling berkaitan, secara garis besar tahapantahapan yang terdapat dalam program kerja meliputi; (1) Lokasi penelitian; (2) Pengumpulan data; (3) Pengambilan data; (4) Analisis data yang digunakan.

\subsection{Lokasi Penelitian}

Lokasi penelitian dilakukan di kawasan P.T. Glostar Indonesia (GSI) pada posisi Km.13 sampai akses masuk jalan baru PT. Pratama Abadi Industri dengan jarak pengamatan 280 meter. Berikut denah lokasi penelitian. 


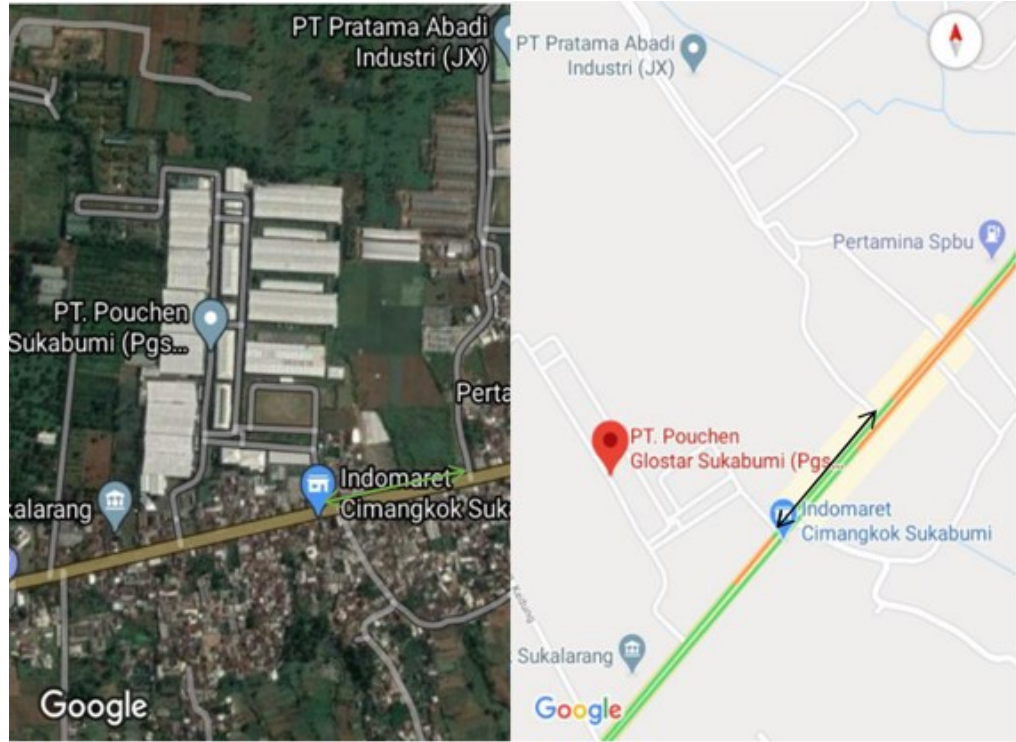

Gambar 1. Lokasi penelitian dilakukan di kawasan P.T. Glostar Indonesia (GSI) pada posisi Km.13

\subsection{Pengumpulan Data}

Data Primer adalah data yang diperoleh dari melakukan langsung survei di lapangan hal ini telah dijelaskan dalam literatur dan literatur terkait didalamnya pada [8]. Data primer dalam penelitian ini di antaranya adalah (1) Volume kendaraan; (2) Kecepatan kendaraan; (3) Hambatan samping; (4) Geometrik jalan. Untuk mendapatkan data kecepatan dan volume lalu lintas yang bervariasi, maka perlu dilakukan survei selama beberapa hari dan dalam beberapa jam pengamatan [9]. Pada penelitian ini, survei dilakukan selama 2 (dua) hari yaitu pada hari Senin (hari kerja) dan hari Sabtu (hari pekan) [10]. Dalam setiap kali survei, pengamatan dilakukan selama 3 (tiga) jam yakni dari pukul $05.30-08.30$ dan di lanjut pukul 11.00-14.00 untuk hari sabtu, sementara itu untuk hari senin dimulai dari pukul 05.30 - 08.30 dilanjut pukul 13.30-16.30 [11]. Dalam pencatatan jumlah dan kecepatan kendaraan dilakukan setiap periode 1 jam [12]. Data Sekunder yaitu data yang diambil dari data orang lain [13], yang dimana di skripsi ini mengambil data dari jurnal Angger Hebat Pradana Program Studi Teknik Sipil, Fakultas Sains dan Teknologi, Universitas Muhammadiyah Sukabumi, untuk dijadikan bahan perbandingan dengan data yang akan diteliti.

- Pengambilan Data Primer; Pada proses pengambilan data, survei dapat dilakukan langsung dilapangan [14], pada titik pengamatan yang sudah ditentukan sebelumnya yang sesuai dengan tujuan penelitian.

- Survei Volume Lalu Lintas; Survei volume lalu lintas secara manual ini dilakukan dengan cara menghitung jumlah kendaraan berdasarkan jenis yang telah ditentukan sebelumnya (HV, LV, MC, UM) [15] dengan menggunakan aplikasi penghitung (Multi Counter) yang melewati titik pengamatan dalam suatu interval waktu tertentu (1 jam) [16].

- Survei Kecepatan Kendaraan; Pengambilan data kecepatan kendaraan dilakukan bersamaan dengan pengambilan data volume lalu lintas. Dalam penelitian ini, survei data kecepatan kendaraan dilakukan dengan menggunakan stopwatch [17].

- Survei Hambatan Samping; Hambatan samping dihitung sepanjang 280 M dengan menggunakan aplikasi penghitung (Multi Counter) yang melewati titik pengamatan dalam suatu interval waktu tertentu (1 jam) [16]. Pengambilan data sekunder yaitu memasukan data yang sudah ada sebelum tahun 2020 yang dimana sempel yang digunakan adalah sempel data dari tahun 2017 yang diambil dari jurnal [3], untuk dijadikan bahan perbandingan dengan data yang akan diteliti. 
- Survei Geometrik Jalan; Survei geometrik jalan yaitu melakukan pengukuran geometrik jalan sebagai data pertama yang diambil [18]. Berikut data geometrik ruas Jalan Sukabumi-Cianjur KM.13 seperti ditampilkan pada Tabel 1.

Tabel 1. Geometrik ruas jalan Sukabumi-Cianjur KM.13.

\begin{tabular}{cc}
\hline Geometrik Ruas Jalan Sukabumi-Cianjur Km.13 \\
\hline Nama Ruas Jalan & Jl. Sukabumi - Cianjur Km. 13 \\
Lebar perkerasan & 8,0 Meter \\
Lebar efektif $(\mathrm{m})$ & 8,0 Meter \\
Lebar Bahu Jalan & $1,5-2$ meter \\
Lalu lintas & $2 / 2 \mathrm{UD}$ \\
Kondisi Permukaan & Baik \\
Median Jalan & Tidak ada \\
Kemiringan & Landai \\
\hline
\end{tabular}

\subsection{Analisis Data Yang Digunakan}

Dalam penelitian ini data-data yang telah diperoleh dari sejumlah survei yang dilakukan akan dianalisis menggunakan Manual Kapasitas Jalan Indonesia (MKJI) 1997 [19], di antaranya; (1) Kapasitas dasar ruas jalan (CO) [20]; (2) Faktor penyesuaian kapasitas untuk lebar jalur lalulintas (Fcw) [21]; (3) Faktor penyesuaian kapasitas untuk pemisahan arah (FCsp) [22]; (4) Faktor penyesuaian kapasitas akibat hambatan samping (FCsf) untuk jalan luar kota Kriteria Tingkat Pelayanan Jalan [23]; (5) Satuan Mobil Penumpang [24]; (6) Faktor Bobot Hambatan Samping Jalan Luar Kota [25]; (7) Kelas Hambatan Samping Untuk Jalan Luar Kota [25]. Berdasarkan uraian analisis yang akan dilakukan dalam penelitian ini akan diketahui volume lalu lintas harian rata-rata, kecepatan lalu lintas rata-rata, hambatan samping harian rata-rata, kapasitas ruas jalan, serta kinerja ruas jalan harian rata-rata. Alur penelitian secara singkat ditampilkan dalam pada Gambar 2.

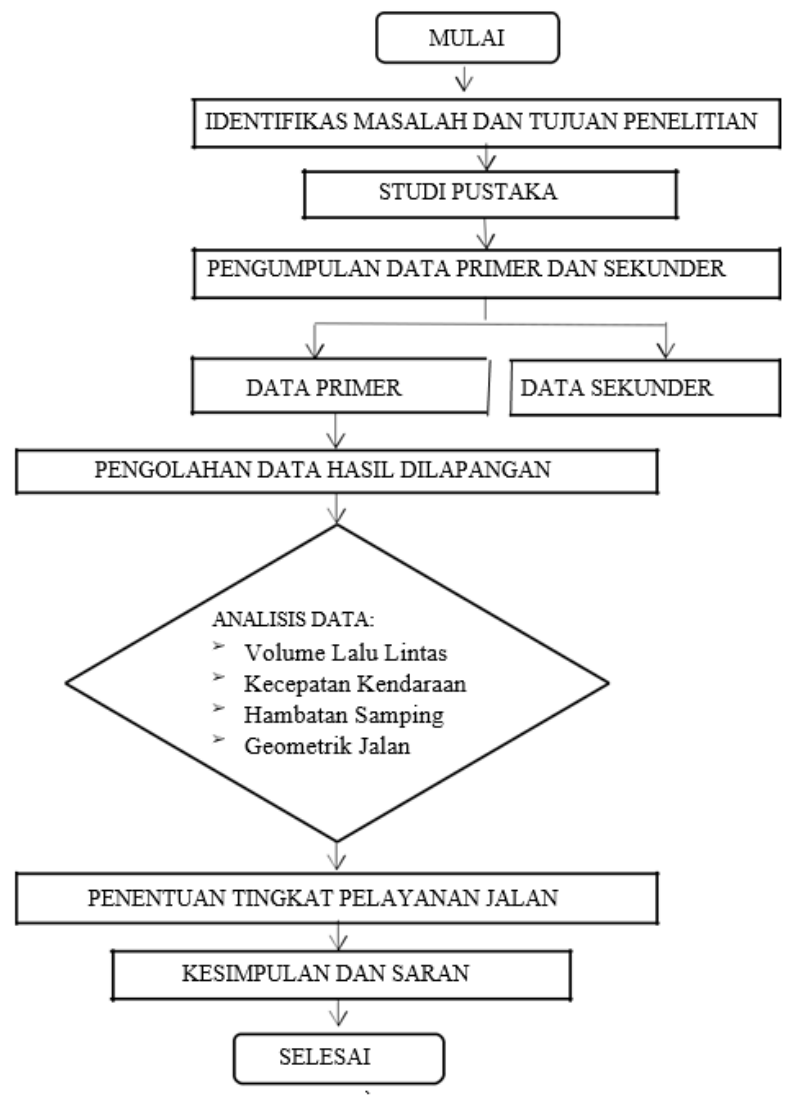

Gambar 2. Alur penelitian 


\section{Hasil dan Pembahasan}

\subsection{Kapasitas Jalan}

Manual Kapasitas Jalan Indonesia (MKJI 1997) memberikan persamaan untuk memperkirakan kapasitas jalan di Indonesia dengan rumus persamaan 1.

$$
\mathrm{C}=\mathrm{CO} \times \mathrm{FCW} \times \mathrm{FCSP} \times \mathrm{FCSF} 1
$$

Keterangan dari persamaan 1 tersebut adalah asebagai berikut, C adalah kapasitas (smp/jam) [26], CO merupakan kapasitas dasar (smp/jam) [27], FCW yaitu faktor penyesuaian lebar jalur lalulintas [12], FCSPadalah faktor penyesuaian pemisahan arah [22], FCSF adalah faktor penyesuaian hambatan samping [28].

\subsection{Kecepatan Perjalanan}

Kecepatan perjalanan (journey/travel speed) mudah untuk diukur dan dimengerti. Kecepatan perjalanan adalah kecepatan rata-rata kendaraan untuk melewati satu ruas jalan. Kecepatan rata-rata kendaraan dapat dihitung menggunakan persamaan 2 berikut:

$\mathrm{V}=\mathrm{L} / \mathrm{TT} \times 36002$

Penjelasan dari persamaan tersebut adalah sebagai berikut, $\mathrm{V}$ adalah kecepatan $(\mathrm{km} / \mathrm{jam})$ [29], L merupakan panjang ruas $(\mathrm{km})$ [12], dan TT yaitu Waktu Perjalanan kendaraan melewati ruas (detik) [3].

\subsection{Kepadatan Ruas}

Kepadatan ruas jalan dapat diukur dengan cara survei input-output, yaitu dengan cara menghitung jumlah kendaraan yang masuk dan keluar pada satu potongan jalan pada suatu periode waktu tertentu. Dalam penelitian ini, kepadatan dihitung dengan rumus dasar [3]. Cara menghitung dapat dilakukan menggunakan persamaan 3 dan 4.

Volume $=$ Kecepatan $\mathrm{x}$ Kepadatan

Maka:

Kepadatan $=$ Volume $/$ Kecepatan

\subsection{Tingkat Pelayanan}

Adapun tingkat pelayanan dilakukan dengan persamaan 5 sebagai berikut:

$\mathrm{D}=\mathrm{V} / \mathrm{C}$

$\mathrm{D}$ adalah nilai tingkat pelayanan jalan (Level of Service) [30]; V merupakan volume lalu lintas (smp/jam) [30], dan C adalah kapasitas ruas jalan (smp/jam) [30]. Tingkat-tingkat ini dinyatakan dengan huruf A yang merupakan tingkat pelayanan tertinggi sampai $F$ yang merupakan tingkat pelayanan paling rendah [31].

\subsection{Satuan Mobil Penumpang}

Satuan mobil penumpang di singkat SMP adalah satuan kendaraan di dalam volume lalulintas yang di setarakan dengan kendaraan ringan/mobil penumpang, dimana besaran SMP dipengaruhi oleh tipe/jenis kendaraan, dimensi kendaraan, dan kemampuan olah gerak. Besaran satuan mobil penumpang bervariasi menurut Manual Kapasitas Jalan Indonesia (MKJI) 1997 [32] ditunjukkan sebagai berikut:

- Kendaraan berat $=1,20$

- Kendaraan ringan $=1,0$

- Sepeda motor $=0,25$

- Kendaraan tidak bermotor $=0,8$ 


\subsection{Volume Lalu Lintas Rata-Rata}

Tingkat layanan ruas jalan di kawasan pabrik GSI sukabumi sebagai pembanding kinerja jalan pada kondisi sebelum pandemic covid-19 dangan tingkat layanan dimasa pandemic covid-19. Berdasarkan studi literatur kondisi kinerja jalan pada tahun 2017 pada hari sabtu seperti ditampilkan pada Tabel 2 [3].

Tabel 2. Volume lalu lintas rata-rata hari sabtu

\begin{tabular}{ccc}
\hline \multirow{2}{*}{ Waktu } & & Total \\
\cline { 2 - 3 } & kendaraan & Smp/jam \\
\hline $05.30-06.30$ & 8018 & 2478,1 \\
$06.30-07.30$ & 3720 & 1374,85 \\
$07.30-08.30$ & 860 & 679,85 \\
$11.00-12.00$ & 5746 & 1894,2 \\
$12.00-13.00$ & 3340 & 1303,15 \\
$13.00-14.00$ & 863 & 677,65 \\
Total & 21684 & 8407,8 \\
\hline
\end{tabular}

Tingkat layanan ruas jalan di kawasan pabrik GSI sukabumi dalam situasi pandemic covid-19 pada tahun 2020 berdasarkan pengamatan secara langsung pada hari sabtu di sajikan dalam Tabel 3.

Tabel 3. Volume lalu lintas rata-rata hari sabtu

\begin{tabular}{ccc}
\hline Waktu & \multicolumn{2}{c}{ Total } \\
\cline { 2 - 3 } & kendaraan & Smp/jam \\
\hline $05.30-06.30$ & 1741 & 898,65 \\
$06.30-07.30$ & 1339 & 656,45 \\
$07.30-08.30$ & 1597 & 839,2 \\
$11.00-12.00$ & 1975 & 1093,95 \\
$12.00-13.00$ & 1676 & 911,4 \\
$13.00-14.00$ & 2143 & 1100,95 \\
Total & 10471 & 5500,6 \\
\hline
\end{tabular}

Dilihat dari Tabel 2 dan Tabel 3 pada hari Sabtu menujukan bahwa pada tahun 2017 total jumlah volume kendaraannya adalah 21684 dan di tahun 2020 mengalami penurunan volume kendaraan yaitu dengan jumlah total 10471 yang dimana penurunan dari tahun 2017 sampai 2020 yaitu 48,3\%. Selanjutnya pendataan volume lalu lintas pada hari senin berdasarkan literatur [3] pada tahun 2017 dan dibandingkan dengan hasil pendataan kondisi pandemic Covid-19 seperti ditampilkan pada Tabel 4.

Tabel 4. Perbandingan volume lalu lintas rata-rata hari senin tahun 2017 denagn tahun 2020

\begin{tabular}{ccc|cc}
\hline \multirow{2}{*}{ Waktu } & & Total tahun 2017 & \multicolumn{2}{c}{ Total tahun 2020 } \\
\cline { 2 - 5 } & kendaraan & Smp/jam & kendaraa & Smp/jam \\
\hline $05.30-06.30$ & 8647 & 2630,4 & 4918 & 1961,75 \\
$06.30-07.30$ & 4762 & 1634 & 4455 & 1557,3 \\
$07.30-08.30$ & 964 & 778,25 & 2220 & 1093,65 \\
$13.30-14.30$ & 1856 & 943,4 & 2903 & 1372,45 \\
$14.30-15.30$ & 3102 & 1224,95 & 4304 & 1784,7 \\
$15.30-16.30$ & 7099 & 2256,35 & 4940 & 1854 \\
Total & 26430 & 9467,35 & 23740 & 9623,85 \\
\hline
\end{tabular}

Dilihat dari Tabel 4 pada hari senin menujukan bahwa pada tahun 2017 total jumlah volume kendaraan adalah 26430 dan di tahun 2020 mengalami penurunya volume kendaraan yaitu dengan jumlah total 23740, sehingga penurunan dari tahun 2017 sampai 2020 yaitu 10,18\%. 


\subsection{Data Kecepatan Sesaat}

Data kecepatan sesaat laju kendaraan yang ditinjau adalah data kecepatan pada kondisi sebelum pandemic covid-19 dan kondisi selama pandemic covid-19 pada tahun 2020. Kecepatan sesaat laju kendaraan pada tahun 2017 [3], kemudian dibandingkan dengan data kecepatan sesaat laju kendaraan pada tahun 2020 diambil sampel pada hari libur yaitu hari sabtu dan hari kerja yaitu hari senin. Perbandingan kecepatan rata-rata pada hari sabtu disajikan pada Tabel 5.

Tabel 5. Perbandingan kecepatan rata-rata hari sabtu tahun 2017 dengan tahun 2020

\begin{tabular}{cccc|ccc}
\hline \multirow{2}{*}{ Waktu } & \multicolumn{3}{c|}{ Tahun 2017 } & \multicolumn{3}{c}{ Tahun 2020 } \\
\cline { 2 - 7 } & Rata-rata & Maks & Min & Rata-rata & Maks & Min \\
\hline $05.30-06.30$ & 1,94 & 11,48 & 0,51 & 55,7 & 76,4 & 26,0 \\
$06.30-07.30$ & 23,51 & 55,99 & 0,78 & 53,3 & 78,5 & 27,3 \\
$07.30-08.30$ & 41,78 & 66,42 & 25,88 & 52,7 & 74,9 & 38,9 \\
$11.00-12.00$ & 3,92 & 11,73 & 0,48 & 48,9 & 75,4 & 31,7 \\
$12.00-13.00$ & 11,57 & 39,39 & 0,83 & 52,9 & 70,6 & 38,9 \\
$13.00-14.00$ & 44,67 & 67,16 & 24,29 & 52,0 & 75,6 & 32,7 \\
\hline
\end{tabular}

Pada Tabel 5 tahun 2017 hari Sabtu merupakan data kecepatan sesaat kendaraan pada waktu akhir pekan dimana jam puncak terdapat pada jam 11.00-12.00 kecepatan sesaat kendaraan paling rendah. Sedangkan kecepatan sesaat yang paling tinggi terdapat pada jam 13.00-14.00. Sementara itu pada tahun 2020 hari Sabtu tidak ada kemacetan yang berarti, karena kecepatan kendaraan tiap jamnya hampir sama. Setelah membandingkan kecepatan kendaraan pada hari libur atau hari sabtu, selanjutnya kecepatan kendaraan perlu ditinjau pada hari kerja. Sampel pendataan kecepatan pada hari kerja yang diambil adalah hari senin. Kecepatan kendaraan pada hari senin pada tahun 2017 mengacu pada literatur [3], sedangkan kecepatan kendaraan pada tahun 2020 pada situasi pandemic covid-19 diambil secara langsung. Perbandingan kecepatan rata-rata hari senin tahun 2017 denagn kecepatan rata-rata pada tahun 2020 disajikan pada Tabel 6 .

Tabel 6. Perbandingan kecepatan rata-rata hari senin tahun 2017 denagn tahun 2020

\begin{tabular}{cccc|ccc}
\hline \multirow{2}{*}{ Waktu } & \multicolumn{3}{c|}{ Tahun 2017 } & \multicolumn{3}{c}{ Tahun 2020 } \\
\cline { 2 - 7 } & Rata-rata & Maks & Min & Rata-rata & Maks & Min \\
\hline $05.30-06.30$ & 1,69 & 9,49 & 0,50 & 29,4 & 48,3 & 4,9 \\
$06.30-07.30$ & 23,67 & 60,10 & 0,73 & 35,9 & 44,4 & 26,9 \\
$07.30-08.30$ & 46,57 & 67,16 & 28,10 & 58,1 & 73,0 & 36,6 \\
$13.30-14.30$ & 8,49 & 15,79 & 3,19 & 42,0 & 60,0 & 31,9 \\
$14.30-15.30$ & 1,18 & 2,05 & 0,74 & 27,8 & 52,6 & 3,7 \\
$15.30-16.30$ & 0,90 & 2,52 & 0,55 & 20,3 & 54,3 & 2,2 \\
\hline
\end{tabular}

Pada Tabel 6 tahun 2017 merupakan data kecepatan sesaat kendaraan pada waktu akhir hari kerja dimana jam puncak terdapat pada jam 05.30-06.30 kecepatan sesaat kendaraan paling rendah. Hal ini disebabkan oleh padatnya kendaraan pada kawasan tersebut untuk melakukan drop penumpang yang akan bekerja di pabrik. Sedangkan kecepatan sesaat yang paling tinggi terdapat pada jam 07.30- 08.30 dimana pada jam tersebut baru saja lepas dari kondisi kemacetan puncak di kawasan pabrik sehingga pergerakan kendaraan sudah lebih leluasa. Sementara itu pada tahun 2020 jam puncak terdapat pada jam 15.30-16.30 karena tidak semua karyawan pekerja datang pada waktu yang sama tetapi semua karyawan pulang kerja pada waktu yang sama yang mengakibatkan terjadi kemacetan, sedangkan kecepatan sesaat yang paling tinggi terdapat pada jam 07.30- 08.30 karena pada jam tersebut merupakn batas waktu masuk jam pekerja.

\subsection{Hambatan Samping}

Analisis hambatan samping adalah mengidentifikasi terjadinya hambatan laju lalu lintas. Hambatan samping yang ditinjau terdiri dari dua arah, yaitu arah Sukabumi-Cianjur dan arah Cianjur-Sukabumi. Hambatan samping yang terjadi berdasarkan literatur [3] dan hasil pengamatan secara langsung diakibatkan oleh adanya pejalan kaki, orang menyeberang jalan, kendaraan berhenti atau parkir, 
kendaraan keluar masuk area pabrik, dan kendaraan melambat. Hambatan samping akan dibandingkan antara tahun 2017 sebelum pandemic covid-19 dan tahun 2020 kondisi pandemic covid-19. Kondisi hambatan samping tahun 2017 [3] dengan tahun 2020 disajikan dalam Tabel 7.

Tabel 7. Data Hambatan Samping Tahun 2017 Dibandingkan Dengan Tahun 2020 Pada Hari Sabtu

\begin{tabular}{ccccccccc}
\hline Waktu & \multicolumn{2}{c}{$\begin{array}{c}\text { Arah Smi-Cjr } \\
\text { org/smp }\end{array}$} & \multicolumn{2}{c}{$\begin{array}{c}\text { Arah Cjr-Smi } \\
\text { org/smp }\end{array}$} & \multicolumn{2}{c}{ Menyeberang } & $\begin{array}{c}\text { Kendaraan } \\
\text { keluar-masuk }\end{array}$ & $\begin{array}{c}\text { Kendaraan } \\
\text { lambat }\end{array}$ \\
\cline { 2 - 9 } [017 & $\mathbf{2 0 2 0}$ & $\mathbf{2 0 1 7}$ & $\mathbf{2 0 2 0}$ & $\mathbf{2 0 1 7}$ & $\mathbf{2 0 2 0}$ & $\mathbf{2 0 2 0}$ & $\mathbf{2 0 2 0}$ \\
\hline $05.30-06.30$ & 3224 & 12 & 2572 & 7 & 2479 & 11 & 8 & 7 \\
$06.30-07.30$ & 1801 & 26 & 1628 & 8 & 1648 & 27 & 6 & 6 \\
$07.30-08.30$ & 3 & 7 & 2 & 21 & 3 & 30 & 10 & 11 \\
$11.00-12.00$ & 2218 & 26 & 2474 & 17 & 2037 & 26 & 17 & 8 \\
$12.00-13.00$ & 1872 & 12 & 2785 & 21 & 2093 & 15 & 9 & 0 \\
$13.00-14.00$ & 45 & 11 & 44 & 41 & 51 & 15 & 12 & 0 \\
\hline
\end{tabular}

Hambatan akibat aktivitas manusia yang terdiri dari pejalan kaki dan menyeberang dengan satuan orang/smp apad tahun 2017 sebelum pandemic covid-19 dibandingkan dengan tahun 2020 dalam situasi pandemic covid-19 pada hari Sabtu, terjadi penurunan yang sangat signifikan seperti dijelaskan pada Tabel 7. Apabila dihitung dari jumlah hambatan samping mengalami penurunan hambatan samping sebesar 99\%, penurunan hambatan samping akibat aktivitas manusia ini akibat diberlakukan PSBB oleh pemerintah. Setelah meninjau dan membandingkan hambatan samping pada hari libur yaitu pada hari Sabtu, selanjutnya ditinjau dan dianalisis hambatan samping pada hari kerja. Hambatan samping pada hari kerja diambil sampel pada hari Senin. Untuk membandingkan hambatan samping pada tahun 2017 sebelum pandemic covid-19 dengan tahun 2020 kondisi pandemic covid-19 dengan ketentuan PSBB, maka data hambatan samping tahun 2017 mengacu pada literatus [3], sedangkan data tahun 2020 kondisi pandemic covid-19 dilakukan pendataan secara langsung. Perbandingan hambatan samping tahun 2017 dengan tahun 2020 kondisi pandemic covid-19 disajikan pada Tabel 8.

Tabel 8. Data Hambatan Samping Tahun 2017 Dibandingkan Dengan Tahun 2020 Pada Hari Senin

\begin{tabular}{cccccccccc}
\hline \multirow{2}{*}{ Waktu } & $\begin{array}{c}\text { Arah Smi- } \\
\text { Cjr org/smp }\end{array}$ & \multicolumn{2}{c}{$\begin{array}{c}\text { Arah Cjr- } \\
\text { Smi org/smp }\end{array}$} & Menyebrang & $\begin{array}{c}\text { Kendaraan } \\
\text { berhenti }\end{array}$ & $\begin{array}{c}\text { Kendaraan } \\
\text { keluar- } \\
\text { masuk }\end{array}$ & $\begin{array}{c}\text { Kendaraan } \\
\text { lambat }\end{array}$ \\
\cline { 2 - 11 } & $\mathbf{2 0 1 7}$ & $\mathbf{2 0 2 0}$ & $\mathbf{2 0 1 7}$ & $\mathbf{2 0 2 0}$ & $\mathbf{2 0 1 7}$ & $\mathbf{2 0 2 0}$ & $\mathbf{2 0 2 0}$ & $\mathbf{2 0 2 0}$ & $\mathbf{2 0 2 0}$ \\
\hline $05.30-06.30$ & 3292 & 552 & 2579 & 544 & 2451 & 615 & 20 & 26 & 5 \\
$06.30-07.30$ & 1833 & 20 & 1596 & 58 & 1706 & 303 & 5 & 6 & 0 \\
$07.30-08.30$ & 4 & 13 & 3 & 11 & 3 & 56 & 5 & 3 & 7 \\
$13.30-14.30$ & 1 & 82 & 1 & 34 & 1 & 123 & 7 & 5 & 2 \\
$14.30-15.30$ & 3 & 22 & 4 & 545 & 4 & 491 & 18 & 8 & 5 \\
$15.30-16.30$ & 4136 & 536 & 5102 & 666 & 4122 & 600 & 28 & 32 & 1 \\
\hline Total & 9269 & 1225 & 9285 & 1858 & 8287 & 2188 \\
\hline
\end{tabular}

Hambatan samping pada hari kerja yaitu hari Senin seperti yang dijelaskan pada Tabel 8, pada tahun 2020 mengalami penurunan hambatan samping dibandingkan dengan tahun 2017. Pejalan kaki pada tahun 2020 arah Sukabumi-Cianjur mengalami penurunan sebesar 87\%, arah Cianjur-Sukabumi mengalami penurunan sebesar $80 \%$, penyeberang jalan mengalami penurunan sebesar $74 \%$ dibandingkan dengan tahun 2017 sebelum pandemic covid-19. Terjadinya penurunan hambatan samping akibat aktivitas manusia ini karena adanya ketentuan PSBB oleh pemerintah.

\subsection{Kapasitas Jalan}

Kapasitas jalan ditinjau dari kondisi hambatan samping, kapasitas dasar (Co) smp/jam, lebar jalur (Fcw), pemisah jalur (FCsp), dan kapasitas ruas jalan (C) smp/jam. Kapasitas jalan akan akan 
dibandingkan antara tahun 2017 sebelum pandemic covid-19 dengan tahun 2020 kondisi pandemic covid-19. Perbandingan ini dilakukan untuk mengetahui bagaimana kapasitas jalan pada kondisi sebelum pandemic covid-19 dengan situasi kondisi pandemic covid-19. Data pembanding kapasitas jalan pada tahun 2017 menggunakan data literatur [3], sedangkan data kapasitas jalan tahun 2020 adalah hasil pendataan secara langsung serta dilakukan analisis kapasitas jalan berdasarkan MKJI 1997 [30]. Kapasitas jalan pada tahun 2017 berdasarkan literatur [3], seperti dijelaskan pada Tabel 9.

Tabel 9. Kapasitas Ruas Jalan Sukabumi-Cianjur KM.13. Tahun 2017 [3]

\begin{tabular}{cccccc}
\hline $\begin{array}{c}\text { Kondisi Hambatan } \\
\text { Samping }\end{array}$ & $\begin{array}{c}\text { Kapasitas Dasar } \\
\text { (Co) Smp/jam }\end{array}$ & $\begin{array}{c}\text { Lebar } \\
\text { jalur } \\
\text { (Fcw) }\end{array}$ & $\begin{array}{c}\text { Pemisah } \\
\text { jalur }\end{array}$ & $\begin{array}{c}\text { Hambatan } \\
\text { Samping (FCsf) }\end{array}$ & $\begin{array}{c}\text { Kapasitas Ruas } \\
\text { Jalan (C) smp/jam }\end{array}$ \\
\hline Sangat Rendah & 3100 & 1,08 & 1,00 & 1,00 & 3348 \\
Sangat Tinggi & 3100 & 1,08 & 1,00 & 0,88 & 2946,24 \\
\hline
\end{tabular}

Pada tahun 2017 kapasitas ruas jalan Sukabumi-Cianjur KM. 13 memiliki hambatan samping sangat rendah pada hari libur dan memiliki hambatan samping sangat tinggi pada hari kerja dengan kapasitas jalan (C) sebesar 2946,24 smp/jam, seperti telah dijelaskan pada Tabel 9. Kapasitas jalan pada tahun 2017 selanjutnya akan dibandingkan dengan kapasitas jalan (C) pada tahun 2020 dalam situasi pandemic covid19. Hasil pendataan secara langsung dan diproses berdasarkan MKJI 1997 kapasitas jalan pada tahun 2020 pada hari libur/Sabtu dijelaskan pada Tabel 10.

Tabel 10. Kapasitas Jalan Pada Hari Sabtu Tahun 2020

\begin{tabular}{cccccccc}
\hline Waktu & & $\begin{array}{c}\text { Kondisi } \\
\text { Hambatan } \\
\text { Samping }\end{array}$ & $\begin{array}{c}\text { Kapasitas } \\
\text { Dasar (Co) } \\
\text { Smp/jam }\end{array}$ & $\begin{array}{c}\text { Lebar } \\
\text { jalur } \\
\text { (Fcw) }\end{array}$ & $\begin{array}{c}\text { Pemisah } \\
\text { jalur }\end{array}$ & $\begin{array}{c}\text { Hambatan } \\
\text { Samping } \\
\text { (FCsf) }\end{array}$ & $\begin{array}{c}\text { Kapasitas } \\
\text { Ruas Jalan (C) } \\
\text { smp/jam }\end{array}$ \\
\hline $05.30-06.30$ & VL & Sangat rendah & 3100 & 1,08 & 1,00 & 1,00 & 3348 \\
$06.30-07.30$ & L & Rendah & 3100 & 1,08 & 1,00 & 0,97 & 3247,56 \\
$07.30-08.30$ & L & Rendah & 3100 & 1,08 & 1,00 & 0,97 & 3247,56 \\
$11.00-12.00$ & L & Rendah & 3100 & 1,08 & 1,00 & 0,97 & 3247,56 \\
$12.00-13.00$ & L & Rendah & 3100 & 1,08 & 1,00 & 0,97 & 3247,56 \\
$13.00-14.00$ & L & Rendah & 3100 & 1,08 & 1,00 & 0,97 & 3247,56 \\
\hline
\end{tabular}

Kapasitas jalan pada hari libur/Sabtu tahun 2020 seperti dijelaskan pada Tabel 10. Memiliki hambatan samping sangat rendah pada pagi hari dengan kapasitas ruas jalan (C) $3348 \mathrm{smp} / \mathrm{jam}$, sedangkan pada waktu pagi menjelang siang jam 06.30-14.00 memiliki hambatan samping rendah, dan kapasitas ruas jalan (C) yang sama yaitu sebesar 3247,56 smp/jam. Selanjutnya perlu ditinjau kapasitas jalan pada hari kerja. Analisis kapasitas jalan pada hari kerja diambil pada hari senin sebagai sampel hari kerja. Hasil analisis kapasitas ruas jalan Sukabumi-Cianjur KM. 13 pada hari senin ditampilkan pada Tabel 11.

Tabel 11. Kapasitas Jalan Pada Hari Senin Tahun 2020

\begin{tabular}{cccccccc}
\hline Waktu & & $\begin{array}{c}\text { Kondisi } \\
\text { Hambatan } \\
\text { Samping }\end{array}$ & $\begin{array}{c}\text { Kapasitas } \\
\text { Dasar } \\
\text { (Co) } \\
\text { Smp/jam }\end{array}$ & $\begin{array}{c}\text { Lebar } \\
\text { jalur } \\
\text { (Fcw) }\end{array}$ & $\begin{array}{c}\text { Pemisah } \\
\text { jalur }\end{array}$ & $\begin{array}{c}\text { Hambatan } \\
\text { Samping } \\
\text { (FCsf) }\end{array}$ & $\begin{array}{c}\text { Kapasitas } \\
\text { Ruas Jalan } \\
\text { (C) smp/jam }\end{array}$ \\
\hline $05.30-06.30$ & VH & Sangat tinggi & 3100 & 1,08 & 1,00 & 0,88 & 2946,24 \\
$06.30-07.30$ & M & Sedang & 3100 & 1,08 & 1,00 & 0,94 & 3147,12 \\
$07.30-08.30$ & L & Rendah & 3100 & 1,08 & 1,00 & 0,97 & 3247,56 \\
$11.00-12.00$ & M & Sedang & 3100 & 1,08 & 1,00 & 0,94 & 3147,12 \\
$12.00-13.00$ & VH & Tinggi & 3100 & 1,08 & 1,00 & 0,88 & 2946,24 \\
$13.00-14.00$ & VH & Sangat tinggi & 3100 & 1,08 & 1,00 & 0,88 & 2946,24 \\
\hline
\end{tabular}

Kapasitas ruas jalan pada tahun 2020 di pagi hari jam 05.30-06.30 dan siang hari kondisi keluarmasuk kerja pabrik sift siang pada jam 12.00-14.00 sebesar (C) 2946,24 smp/jam dengan hambatan samping sangat tinggi. Sedangkan pada jam 06.30-07.30 dan 11.00-12.00 memiliki kapasitas ruas jalan (C) 3147,12 dengan hambatan samping sedang seperti telah dijelaskan pada Tabel 11. 


\subsection{Analisis Kinerja Ruas Jalan}

Kinerja ruas jalan ditinjau berdasarkan waktu pendataan kendaraan, volume lalu lintas smp/jam, kapasitas jalan smp/jam, tingkat pelayanan jalan, yang kemudian kinerja ruas jalan disimpulkan berdasarkan katagori tingkat pelayanan jalan. Kinerja ruas jalan akan dibandingkan pada kondisi sebelum pandemic covid-19 tahun 2017 dengan kondisi saaat ini dalam situasi pandemic covid-19 tahun 2020. Waktu pengamatan dilakukan mulai dari pagi hari jam 05.30-14.00 pada hari libur/Sabtu dan hari kerja/senin. Kinerja ruas jalan pada tahun 2017 berdasarkan literatur [3], di sajikan pada Tabel 12.

Tabel 12. Hasil Analisa Kinerja Ruas Jalan Rata-Rata Pada Hari Sabtu Tahun 2017 Dibandingkan Dengan Tahun 2020

\begin{tabular}{ccccccccc}
\hline \multirow{2}{*}{ Waktu/Tahun } & \multicolumn{2}{c}{$\begin{array}{c}\text { Volume lalu } \\
\text { lintas smp/jam }\end{array}$} & \multicolumn{2}{c}{$\begin{array}{c}\text { Kapasitas jalan } \\
\text { smp/jam }\end{array}$} & \multicolumn{2}{c}{ V/C } & \multicolumn{2}{c}{$\begin{array}{c}\text { Tingkat pelayanan } \\
\text { jalan }\end{array}$} \\
\cline { 2 - 10 } & $\mathbf{2 0 1 7}$ & $\mathbf{2 0 2 0}$ & $\mathbf{2 0 1 7}$ & $\mathbf{2 0 2 0}$ & $\mathbf{2 0 1 7}$ & $\mathbf{2 0 2 0}$ & $\mathbf{2 0 1 7}$ & $\mathbf{2 0 2 0}$ \\
\hline $05.30-06.30$ & 2478,1 & 898,65 & 2946,24 & 3348 & 0,841 & 0,268 & $\mathrm{D}$ & $\mathrm{B}$ \\
$06.30-07.30$ & 1374,85 & 656,45 & 2946,24 & 3247,56 & 0,467 & 0,202 & $\mathrm{C}$ & $\mathrm{A}$ \\
$07.30-08.30$ & 679,85 & 839,2 & 3348 & 3247,56 & 0,203 & 0,258 & $\mathrm{~A}$ & $\mathrm{~B}$ \\
$13.30-14.30$ & 1894,2 & 1093,95 & 2946,24 & 3247,56 & 0,643 & 0,337 & $\mathrm{C}$ & $\mathrm{B}$ \\
$14.30-15.30$ & 1303,15 & 911,4 & 2946,24 & 3247,56 & 0,442 & 0,281 & $\mathrm{~B}$ & $\mathrm{~B}$ \\
$15.30-16.30$ & 677,65 & 1100,95 & 2946,24 & $3,247,56$ & 0,230 & 0,339 & $\mathrm{~B}$ & $\mathrm{~B}$ \\
\hline
\end{tabular}

Tingkat pelayanan jalan hari libur/Sabtu pada tahun 2017 menunjukkan bahwa terjadi tingkat paling rendah kinerja jalan pada jam puncak lalu lintas kawasan pabrik GSI dan sekitarnya yakni pada angka 0.841 atau LoS D, artinya terjadi kemacetan sampai terjadi stagnasi kendaraan di Kawasan Pabrik GSI akibat pergerakan kendaraan dan orang seperti dijelaskan pada Tabel 12. Tingkat pelayanan jalan pada tahun 2020 menunjukkan bahwa hambatan samping pada hari sabtu rendah (tingkat pelayanannya tinggi), tidak terjadi kemacetan, dan rata-rata LoS pada hari Sabtu adalah B, artinya tingkat pelayanan jalan baik, hal ini terjadi karena masih dalam masa pandemi covid-19 sehingga pengendara tidak banyak yang berlalu Lalang. Selanjutnya meninjau kinerja ruas jalan pada hari kerja, dengan mengambil sampel hari Senin. Perbandingan kinerja ruas jalan pada hari kerja antara tahun 2017 dengan tahun 2020 di jelaskan pada Tabel 13 .

Tabel 13. Hasil Analisa Kinerja Ruas Jalan Rata-Rata Pada Hari Senin Tahun 2017 Dibandingkan Dengan Tahun 2020

\begin{tabular}{ccccccccc}
\hline \multirow{2}{*}{ Waktu/Tahun } & \multicolumn{2}{c}{$\begin{array}{c}\text { Volume lalu } \\
\text { lintas smp/jam }\end{array}$} & \multicolumn{2}{c}{$\begin{array}{c}\text { Kapasitas jalan } \\
\text { smp/jam }\end{array}$} & \multicolumn{2}{c}{ V/C } & \multicolumn{3}{c}{$\begin{array}{c}\text { Tingkat pelayanan } \\
\text { jalan }\end{array}$} \\
\cline { 2 - 9 } & $\mathbf{2 0 1 7}$ & $\mathbf{2 0 2 0}$ & $\mathbf{2 0 1 7}$ & $\mathbf{2 0 2 0}$ & $\mathbf{2 0 1 7}$ & $\mathbf{2 0 2 0}$ & $\mathbf{2 0 1 7}$ & $\mathbf{2 0 2 0}$ \\
\hline $05.30-06.30$ & 2630,4 & 1961,75 & 2946,24 & 2946,24 & 0,8928 & 0,666 & $\mathrm{E}$ & $\mathrm{C}$ \\
$06.30-07.30$ & 1634 & 1557,3 & 2946,24 & 3147,12 & 0,55461 & 0,495 & $\mathrm{C}$ & $\mathrm{C}$ \\
$07.30-08.30$ & 778,25 & 1093,65 & 3348 & 3247,56 & 0,23245 & 0,348 & $\mathrm{~B}$ & $\mathrm{~B}$ \\
$13.30-14.30$ & 943,4 & 1372,45 & 2946,24 & 3147,12 & 0,3202 & 0,436 & $\mathrm{~B}$ & $\mathrm{~B}$ \\
$14.30-15.30$ & 1224,95 & 1784,7 & 2946,24 & 2946,24 & 0,41577 & 0,606 & $\mathrm{~B}$ & $\mathrm{C}$ \\
$15.30-16.30$ & 2256,35 & 1854 & 2946,24 & 2946,24 & 0,76584 & 0,629 & $\mathrm{D}$ & $\mathrm{C}$ \\
\hline
\end{tabular}

Tingkat pelayanan jalan pada hari Senin tahun 2017 menunjukkan bahwa terjadi tingkat pelayanan jalan paling sangat rendah kinerja jalan pada jam puncak lalu lintas kawasan pabrik GSI dan sekitarnya yakni pada angka 0.8928 atau LoS E, yang mengandung arti terjadi kemacetan sampai terjadi stagnasi kendaraan di Kawasan Pabrik GSI akibat pergerakan kendaraan dan orang pada jam 05.30-06.30 seperti dijelaskan pada Tabel 13. Sedangkan pada tahun 2020 menunjukkan bahwa hambatan samping pada hari Senin sedang, hanya terjadi kemacetan pada jam masuk dan jam keluar kerja, dengan rata-rata LoS C, artinya tingkat pelayanan jalan sedang, karena masih dalam masa pandemi covid-19. Dari Hasil survei kendaraan yang banyak lewat yaitu dari karyawan pabrik yang masuk dan keluar kerja. 


\section{Kesimpulan}

Kinerja ruas jalan pada situasi pandemic covid-19 dapat dinyatakan lebih baik jila dibandingkan dengan tahun 2017 sebelum pandemic covid-19. Kondisi baik kinerja ruas jalan ditandai dengan berkurangnya volume kendaraan, kecepatan kendaraan meningkat, kepadatan kendaraan berkurang, sehingga tingkat pelayanannya baik. Dari data yang diperoleh maka pandemi covid-19 berpengaruh terhadap volume lalu lintas dan kinerja ruas jalan, sehingga mengalami penurunan volume kendaraan dan menurunkan tingkat kemacetan di tahun 2020. Pada tahun 2017 volume lalu lintas pada hari Sabtu yaitu 21684 kendaraan dan 8407,8 smp/jam, sedangkan pada tahun 2020 hari Sabtu sebanyak 10471 kendaraan dengan 5500,6 smp/jam mengalami penurunan sebanyak 48,3\%. Sementara di tahun 2017 volume lalu lintas pada hari Senin sebanyak 26430 kendaraan dengan 9467,35 smp/jam, sedangkan pada tahun 2020 hari Senin sebanyak 23740 kendaraan dengan 9623,85 smp/jam mengalami penurunan sebanyak 10,18\%. Kondisi kinerja jalan yang baik pada situasi pandemic covid-19 selanjutnya dapat dijadikan referensi dalam mengatur rekayasa lalu lintas pada kondisi normal setelah pandemic covid-19 agar tidak terjadi kemacetan dengan tingkat kejenuhan yang tinggi

\section{Daftar Pustaka}

[1] R. S. Alfandani, "Analisis Tingkat Kemacetan Lalu Lintas Dengan Memanfaatkan Citra Ikonos Dan SIG Di Ruas Jalan Letjend Suprapto, Jalan Ki Mangunsarkoro Dan Jalan Sumpah Pemuda Kota Surakarta." Universitas Muhammadiyah Surakarta, 2016. Diakses dalam Google Scholar

[2] R. Gunawan and T. Zulham, "Hubungan Kemacetan Lalu Lintas Dengan Pendapatan Dan Pengeluaran Pedagang Di Kota Banda Aceh," J. IIm. Mhs. Ekon. Pembang., vol. 3, no. 2, pp. 168-176, 2018. Diakses dalam Google Scholar

[3] A. H. Pradana, "Tingkat Layanan Ruas Jalan Di Kawasan Pabrik GSI Sukabumi." Diakses dalam Google Scholar

[4] S. Sumadi, "Menakar Dampak Fenomena Pandemi Covid-19 Terhadap Perbankan Syariah," J. Huk. Ekon. Syariah, vol. 3, no. 2, pp. 145-162, 2020. doi: 10.30595/jhes.v0i1.8761

[5] E. Burhan, "Coronavirus yang meresahkan dunia," J. Indones. Med. Assoc., vol. 70, no. 2, pp. 1-3, 2020. doi: 10.47830/jinma-vol.70.2-2020-170

[6] M. N. Mahardika, A. Trisiana, A. Widyastuti, J. S. Juhaena, and R. M. A. Kirani, "Strategi Pemerintah dan Kepatuhan Masyarakat dalam Mengatasi Wabah Covid-19 Berbasis Semangat Gotong Royong," J. Glob. Citiz. J. Ilm. Kaji. Pendidik. Kewarganegaraan, vol. 9, no. 1, pp. 39-50, 2020. Diakses dalam Google Scholar

[7] F. Zulkarnain, A. A. Nurdin, N. Gojali, and F. P. Wahyu, "Kebijakan fatwa MUI meliburkan shalat jumat pada masa pandemi Covid 19," Kebijak. fatwa MUI meliburkan shalat jumat pada masa pandemi covid 19, 2020. Diakses dalam Google Scholar

[8] M. Akbar, E. Budianto, and B. Doloksaribu, "Penentuan Besarnya Tarif Angkutan Dalam Kota (Angkot) Dengan Metode BOK," Musamus J. Civ. Eng., vol. 1, no. 2, pp. 12-15, 2019. Diakses dalam Google Scholar

[9] A. Nego, R. S. Suyono, and S. N. Kadarini, "Model Hubungan Volume Kecepatan dan Kerapatan Pada Jalan Jendral Ahmad Yani 1 Pontianak," J. Mhs. Tek. Sipil Univ. Tanjungpura, vol. 5, no. 2, 2018. Diakses dalam Google Scholar

[10] V. Imandita, "Analisis Kebisingan Dan Volume Lalu Lintas Kendaraan Di Jalan Ketintang Kota Surabaya," Swara Bhumi, vol. 5, no. 7, 2018. Diakses dalam Google Scholar

[11] J. A. Jhora, "Analisis Pengukuran Waktu Kerja Dengan Menggunakan Metode Work Sampling (Studi Kasus: Pt. Dunia Barusa-Toyota Banda Aceh)," ETD Unsyiah, 2015. Diakses dalam Google Scholar

[12] M. V. M. Septiansyah and D. N. Wulansari, "Analisa Kinerja Ruas Jalan Medan Merdeka Barat, DKI Jakarta," J. Kaji. Tek. Sipil, vol. 3, no. 2, pp. 110-115, 2018. Diakses dalam Google Scholar

[13] S. M. Dalimunthe, "Gambaran faktor-faktor kejadian stunting pada balita usia 24-59 bulan di Provinsi Nusa Tenggara Barat tahun 2010 (analisis data sekunder riskesdas 2010)." UIN Syarif Hidayatullah Jakartal: Fakultas Kedokteran Dan IImu Kesehata, 2015, 2015. Diakses dalam Google Scholar

[14] P. Bartolomeus Krismanto, "Analisis Pertumbuhan Arus Penumpang Terhadap Kinerja Fasilitas Gedung Terminal Bandar Udara Mopah, Merauke." UAJY, 2018. Diakses dalam Google Scholar 
[15] G. Fitri, R. Rosalina, and M. A. Munandar, "Evaluasi Kinerja Simpang Bersinyal Empat Lengan pada Simpang Inpres Kota Lhokseumawe," Portal J. Tek. Sipil, vol. 8, no. 2, 2018. doi: 10.30811/portal.v8i2.604

[16] A. Ginanjar and I. Farida, "Pemodelan Simpang Bersinyal Terhadap Kinerja Simpang Jalan Terusan Pembangunan dan Jalan Proklamasi di Kabupaten Garut," J. Konstr., vol. 17, no. 1, pp. 1-8, 2019. Diakses dalam Google Scholar

[17] A. I. Titirlolobi, E. Lintong, and J. A. Timboeleng, "Analisa Kinerja Ruas Jalan Hasanuddin Kota Manado," J. Sipil Statik, vol. 4, no. 7, 2016. Diakses dalam Google Scholar

[18] F. D. Mulyono, "Evaluasi Geometrik-Kinerja dan Perkerasan Lentur Jalan Pantai Utara (PANTURA)." UNIVERSITAS MUHAMMADIYAH JEMBER, 2018. Diakses dalam Google Scholar

[19] B. Jatmika, M. Pallah, N. Akmaliyah, A. Sardi, R. F. K. Barkah, and I. A. Darmawan, "The Evaluation on the Saturation Degree on Pelabuhan II Street of Sukabumi City," in 2018 International Conference on Computing, Engineering, and Design (ICCED), 2018, pp. 208-211. doai: 10.1109/ICCED.2018.00048

[20] C. Novalia, R. Sulistyorini, and S. Putra, "Analisa dan Solusi Kemacetan Lalu Lintas di Ruas Jalan Kota (Studi Kasus Jalan Imam Bonjol-Jalan Sisingamangaraja)," J. Rekayasa Sipil dan Desain, vol. 4, no. 1, pp. 153-162, 2016. Diakses dalam Google Scholar

[21] T. G. S. Merentek, T. K. Sendow, and M. R. E. Manoppo, "Evaluasi Perhitungan Kapasitas Menurut Metode MKJI 1997 dan Metode Perhitungan Kapasitas dengan Menggunakan Analisa Perilaku Karakteristik Arus Lalu Lintas Pada Ruas Jalan Antar Kota (Studi Kasus Manado-Bitung)," J. Sipil Statik, vol. 4, no. 3, 2016. Diakses dalam Google Scholar

[22] D. Hamdani and A. A. Anisarida, "Identifikasi Kapasitas Ruas Jalan Letjen Ibrahim Adjie Sta. 3+ 100 Di Perlintasan Sebidang Kereta Api Kota Tasikmalaya," J. Tek. Sipil Cendekia, vol. 1, no. 1, pp. 45-57, 2020. doi: 10.51988/vol1no1 bulanjulitahun2020.v111.7

[23] R. KHAERUR, "ANALISA KINERJA RUAS JALAN AKIBAT ADANYA HAMBATAN SAMPING (Studi Kasus: Jalan Gajah Mada Kota Mataram)." UNIVERSITAS MUHAMMADIYAH MATARAM, 2020. Diakses dalam Google Scholar

[24] F. Taidi, S. Y. R. Rompis, and M. E. Manoppo, "ANALISIS NILAI EKIVALENSI MOBIL PENUMPANG PADA SIMPANG BERSINYAL DI KOTA MANADO," J. SIPIL STATIK, vol. 6, no. 2, 2018. Diakses dalam Google Scholar

[25] R. Syaputra, S. Sebayang, and D. Herianto, "Pengaruh Hambatan Samping Terhadap Kinerja Lalu Lintas Jalan Nasional (Studi Kasus Jalan Proklamator Raya-Pasar Bandarjaya Plaza)," J. Rekayasa Sipil dan Desain, vol. 3, no. 3, pp. 441-454, 2016. Diakses dalam Google Scholar

[26] D. Indratmo, "Kajian Kapasitas Jalan dan Derajat Kejenuhan Lalu-Lintas di Jalan Ahmad Yani Surabaya," J. Apl. Tek. Sipil, vol. 1, no. 1, pp. 25-31, 2017. doi: 10.12962/j12345678.v1i1.2773

[27] R. Anisari, "Analisa Kapasitas Jalan Dan Derajat Kejenuhan Berdasarkan Survey Lalu Lintas Harian Rata-Rata Di Kabupaten Paser Kalimantan Timur," J. Gradasi Tek. Sipil, vol. 1, no. 2, pp. 62-69, 2017. doi: 10.31961/gradasi.v1i2.435

[28] T. K. Senduk, A. L. E. Rumayar, and S. C. N. Palenewen, "Pengaruh Hambatan Samping Terhadap Kinerja Ruas Jalan Raya Kota Tomohon (Studi Kasus: Persimpangan JL. Pesanggrahan-Persimpangan JL. Pasuwengan)," J. Sipil Statik, vol. 6, no. 7, 2018. Diakses dalam Google Scholar

[29] N. M. Sari and A. Novia, "Tinjauan Kecepatan Kendaran Pada Wilayah Zona Selamat Sekolah (Zoss) Di Kota Padang," 2015. Diakses dalam Google Scholar

[30] R. Kristanti, R. Rachman, and L. E. Radjawane, "Analisis Dampak Hambatan Samping Terhadap Tingkat Pelayanan Jalan Kota Makassar," Paulus Civ. Eng. J., vol. 2, no. 2, pp. 85-91, 2020. doi: 10.52722/pcej.v2i2.133

[31] O. Y. A. Saputra, "Analisa Kapasitas Pelayanan Lalu Lintas Jalan Slamet Riyadi-Bung Tomo-Dr. Cipto Mangunkusumo Terhadap Pembangunan Jembatan Mahakam Iv Kota Samarinda," Kurva S J. Mhs., vol. 1, no. 1, pp. 644-666, 2019. Diakses dalam Google Scholar

[32] T. B. Joewono, K. M. H. N. Nugraha, and Z. Alviana, "Estimasi Ekivalensi Mobil Penumpang Berdasar Data Kecepatan Pada Jalan Tol," 2018. Diakses dalam Google Scholar 